UDK 311.312(100+477)

O. H. Osaulenko,

Doctor of Public Administration, Professor, Corresponding Member of the NAS of Ukraine, Honored Economist of Ukraine,

Rector

National Academy of Statistics, Accounting and Audit,

E-mail: dasoa@nasoa.edu.ua

\title{
Experience of Introduction of National Principles Governing the Activity of the State Statistics Bodies of Ukraine
}

The paper analyzes the role of the Fundamental Principles of Official Statistics in the development of the Ukrainian statistical system and its adaptation to international standards.

The adoption and implementation of the Fundamental Principles, their subsequent development in the European Statistics Code of Practice (2005) and explanation in the National Principles Governing the Activity of the State Statistics Bodies of Ukraine (2010) served as a clear benchmark for setting priorities in the state statistical activity. It should be noted that not all of the principles could be equally easy implemented in the existing statistical practice. Even today, two decades after the adoption of the Fundamental Principles of Official Statistics, there is still a number of debating points in their practical implementation.

Special attention is given to the compilation of the National Principles Governing the Activity of the State Statistics Bodies of Ukraine that are based on the European Statistics Code of Practice and incorporate PARIS21 system of indicators. The principles have been developed and implemented with the goal to create the basis for further strengthening of the institutional capacity of national statistical office, to implement the best practices of the European statistics, and on this basis to enhance user confidence in the official statistics and ensure high-quality statistical information.

Key words: European Statistics Code of Practice, Statistical Standards of Eurostat, National Principles Governing the Activity of the State Statistics Bodies of Ukraine, self-assessment, process-oriented approach.

The State Statistics Service of Ukraine (hereinafter - SSSU) started to create national principles of activity of the state statistics bodies in 2008 within the scope of system work on adaptation of standard-legal base in the sphere of statistics to EU requirements.

It is necessary to note that successful preparation of this fundamental document was substantially promoted by the whole complex of conducted actions which results became the reliable basis for working out of National Principles Governing the Activity of the State Statistics Bodies of Ukraine.

After approval of the European Statistics Code of Practice (hereinafter - $\mathrm{CoP}$ ) by the Committee of EU on statistical programs in 2005, principles and indicators of this Code as well as the subsequent actions of Eurostat and the European statistical services had been analyzed in detail by the SSSU on its introduction in practice, in particular carrying out of selfassessments and peer reviews, organized by Eurostat.

Practically during the same time (over a period of 2007-2009), the SSSU carried out the functional survey. This work was realized in two steps: the first step involved the central level - the SSSU, the second - its territorial bodies. Primary aim of functional inspection of the SSSU was specification of its functions and revision of the Regulations of the SSSU activities.

(c) O. H. Osaulenko, 2017
Taking into account the results of the functional inspection of the SSSU in 2007, the Government of Ukraine approved Regulations of the SSSU activities, and then the SSSU approved standard regulations concerning structural divisions of the Service.

Besides, in 2008, the SSSU interviewed the representatives of the administrative board and staff of the SSSU structural divisions about the set-up of their work, working conditions, quality of information services provided to users of the statistical data, etc. Simultaneously, in the process of interviewing, the offers on improvement of the SSSU activity were put forward.

Results of functional inspection and questioning of staff were used in preparation of the Regulations of the SSSU, and also at forming basic documentation of quality control system of the SSSU. The quality manual, including the list of key processes of the SSSU activity, were thus confirmed, people responsible for their functioning were identified as well as the list of services provided and categories of users.

Within 2009, the same functional inspections were conducted in territorial bodies of the state statistics. Based on received results, the SSSU approved the Standard documentation of quality control system, introduced some changes into the Standard regulations and Standard provisions for territorial bodies of the state statistics. 
To develop the order of work on introduction of quality control system, the SSSU initiated self-assessments of compliance of its activity with the principles of the European Statistics Code of Practice. With that aim in view, in 2008 in the SSSU, the working group on preparation and carrying out of self-assessment was formed, its plan-schedule was devised and provided the performance of the following actions:

creation of the national questionnaire on selfassessment of compliance of the SSSU activity with the principles of the Code on the basis of the CoP Questionnaire; staff;

set-up of appropriate training for the SSSU

direct self-assessment with the support of the SSSU management and its structural divisions;

generalization of received materials and consideration of self-assessment results at the sessions of the SSSU advisory bodies.

Self-assessment has allowed to receive information concerning positioning of national statistical system with reference to the European one, and also to gain absolutely new experience on revealing of priority spheres of development for further upgrading and improvement of the state statistics quality. As consequence, these results laid down the basis for the Strategy of the State Statistics Development for the Period till 2012, approved by the decision of the Cabinet of Ministers of Ukraine (further - Strategy 2012).

Preparation of National Principles Governing the Activity of the State Statistics Bodies harmonized with the European Statistics Code of Practice, and determination of the order for self-assessment of activity on a regular basis became one of the major topics of this long-term program of the state statistics development. The objectives of these National Principles are:

strengthening of users trust to the state statistics bodies, based on impartiality, objectivity and independence of the state statistical activity;

- guaranteeing of confidentiality of the statistical data received from respondents;

- introduction of the best experience of the European statistics into national practice.

Experts of the National Institute of Statistics of Denmark have joined this work at the final stage of preparation of National Principles Governing the Activity. In the first half of 2010 , within the framework of the Twinning light project "Harmonization of official statistics of Ukraine with statistical standards of EU", the draft of National Principles Governing the Activity was thoroughly discussed with Danish colleagues and, in May of the same year, the definitive edition of the draft document received positive assessment and was recommended for the SSSU approval.

At the beginning of June 2010, the draft of National Principles Governing the Activity of the State Sta- tistics Bodies was considered and approved at the session of board of the State Statistics Service. Afterwards it was confirmed by the SSSU order and placed on its site with necessary comments for public information.

To the basis for National Principles Governing the Activity was laid down: total quality management (hereinafter - TQM) concept, standards of quality control system of 9000 series, Model of the European Foundation of the Quality Management (hereinafter - EFQM), the European Statistics Code of Practice, the Standard of the European statistical system of quality reports of 2009 and Statistical Capacity Monitoring done according to PARIS21 technique. First of all, the SSSU considered that indicators for these concepts, systems and models can be used both for assessment of compliance of the state statistical activity in Ukraine with the standards of the European statistical system, and for national (internal) review of activity set-up at statistical divisions.

It is necessary to underline that National Principles Governing the Activity are fully harmonized with the European Statistics Code of Practice. At the same time, unlike the last, they include not 15, but 18 principles. Herewith National Principles Governing the Activity contain all the 15 principles of the CoP. In addition, they include three more principles: "Management and professional ethics" (4 indicators), "Effectiveness of activity" (3 indicators) and "Ongoing improvements" (3 indicators). Thus, principle 12 is supplemented with a number of indicators characterizing cooperation not only with respondents, but also with all other subjects participating in realization of the state statistical activity. It reflected in the principle name "Partnership relations in statistical activity" (in the European Statistics Code of Practice - principle 9 "Non-excessive burden on respondents"). Moreover, the set of indicators for principle 13 "Cost effectiveness" (in the CoP - principle 10 with the similar name) has been expanded.

All additions set forth above were approved by international experts as were caused by the need to establish the corresponding environment for constant improvement of activity and the accurate mechanism for maintenance of further development and quality improvement in the system of the state statistics bodies on this basis.

In 2011, the European Commission (Eurostat), the European Free Trade Association (EFTA) and the UN Economic Commission for Europe (UNECE) in the framework of the EU financial project "Global assessments of statistical systems of candidate countries and potential candidates and ENP countries" conducted the Adapted Global Assessment of the Ukrainian national statistical system (hereinafter - AGA) in the SSSU.

According to the assessment of international experts, the institutional environment of functioning of 
the state statistics bodies of Ukraine was recognized as generally compliant with the statistical standards of Eurostat, primarily the UN Fundamental Principles of Official Statistics and the CoP as well as the Compendium of statistical requirements of Eurostat. At the same time, the expert group recommended to harmonize national legislation in the field of statistics and in related areas with the EU legislation, to improve some statistical procedures and to continue the implementation of the process-oriented approach in the statistical activity, using the methods and techniques used in the European statistics.

According to the AGA recommendations, in 2012 on the basis of the DESAP questionnaire (Development of a Self-Assessment Programme / the European self-assessment questionnaire for the head of the statistical observation), the SSSU developed the national questionnaire - the development of selfassessment program for the head of state statistical observation (hereinafter - the DSAP questionnaire). The DSAP questionnaire was filled in by all heads of state statistical observations, and their total average rating of quality by five-point grading scale was 4.2 .

The AGA results and self-assessment by the RPS questionnaire laid the basis for the development of the current five-year statistical program - Strategy of Development of State Statistics of Ukraine for the period until 2017 (hereinafter - the Strategy 2017). The purpose of the Strategy 2017 is to improve the quality of state statistics by developing a holistic effective national system of official statistics and to bring it in line with the EU standards.

The mainstream directions of the five-year statistical program are: to improve the quality of the state statistical activity by ensuring data quality assessment of state statistical observations according to the criteria of the European statistical system and the publication of assessment results for the users of statistical information; to develop the management of statistical production processes and assessment of the results of state statistical activity; to improve the quality of measurement on resource adequacy of the state statistical activity and evaluating of its effectiveness

In order to improve the management of statistical production, the current five-year program (the Strategy 2017) provided for the introduction of the process-oriented approach in the planning of the state statistics bodies, monitoring, audit and evaluation of the results.

In 2013-2015, the SSSU made the arrangements for the implementation of process-oriented approach into planning of statistical activities. The formation of the functional program based on process model allows standardizing the description of the procedures and operations carried out within the framework of various state statistical observations.
Process-oriented approach was introduced into monitoring and evaluation of results in 2012. The tool for monitoring and evaluation of the activities within the state statistics bodies is provided by the system of self-assessment questionnaires, which encompasses, in addition to the above mentioned RPS questionnaire (developed on the basis of the DESAP questionnaire), the following items:

1. Self-assessment questionnaire on the improvement of the state statistical observation (for the head of state statistical observation);

2. Self-assessment questionnaire on the activities of the territorial body of statistics to improve state statistical observations (for the regional state statistics bodies);

3. Self-assessment questionnaire on the functioning of processes (sub-processes) of statistical production (for the authorized employee responsible for the implementation of procedures and operations for the improved organization of state statistical observations);

Moreover, since 2013, the SSSU has been conducting peer reviews of the performance of the regional state statistics bodies that are also based on the process-oriented approach.

Thus, the self-assessment is based on three harmonized documents of international, European and national levels: Fundamental Principles of Official Statistics, European Statistics Code of Practice and the National Principles Governing the Activity of the State Statistics Bodies of Ukraine. The interrelation and consistency of the various assessments of activity allows, firstly, to conduct comprehensive study on the development, and secondly, to streamline selfassessment as well as reduce the burden on the monitoring participants by eliminating duplications of characteristics and identification of target groups of respondents. In addition, the regular and systematic self-assessment provides the possibility of creating a unique information base to monitor trends and establish cause-to-effects relations. Thus, the more compliance assessment of activities will correspond to $\mathrm{Na}$ tional Principles Governing the Activity, the higher is the quality of the statistical production.

The Strategy 2017 also provides for the system of preparation and publication of the quality data reports on state statistical observations. In order to establish common approaches to the preparation of quality reports, in 2014, the SSSU developed the Guidelines for the preparation of standard report on the quality of statistical observation that meet the ESS Standard on quality reports of 2009. The scheduled plan was compiled on preparation of standard reports on the quality of state statistical observations. The document stipulated the preparation of a standard quality report on each state statistical observation. These reports are intended for being posted on the SSSU website. 
Thus, over the past five years, the SSSU established concrete prerequisites for further standardization of the production process and enhancement of its performance on this basis by "industrialization" of statistical production.

Application of the ESS standard quality reports and implementation of the process-oriented approach to the organization of activity opens up new possibilities for improved statistical production:

- it allows a systematic analysis of certain aspects of the statistical production, including the analysis of the development trends;

enables comprehensive assessments of the obtained results and provides the grounds for decisions on further actions to improve them;

- provides the means for identification of the information flows, produced and circulating in the SSSU and also interacting with the external environment, and their differentiated analysis by management function (with the differentiation of the direct production functions as well as accounting, planning and analysis functions);

creates conditions for the development of new approaches to the organization of the production process applying the Generic Statistical Information Model (GSIM) and on the basis of data and metadata for different groups of users within the system of state statistics bodies and beyond.

What are the means that we see as possibility for the practical implementation of the National Principles Governing the Activity? This is the harmonization of the organizational structure with the process-oriented scheme of statistical activities and introduction of the monitoring system as indicated above.

The challenge is that the existing institutional structure largely fails to meet the up-to-date requirements, as the "owners" (the units responsible for the operation of these processes) of certain share of the processes have not been clearly identified.

So, as for today, the state statistics bodies of Ukraine face the task of creating a new organizational structure that will be fully consistent with the process-oriented scheme of statistical production. The work was launched in December 2015 with the development of the new organizational structure of the territorial bodies of the SSSU that provided for the introduction of a process-oriented approach to the production of statistics and statistical organization in accordance with the adapted version of the Generic Statistical Business Process Model (GSBPM), recommended by international statistical organizations for national statistical offices in different countries. The total number of employees of state statistics bodies was reduced by 20 per cent, half of the remote units of the district (city) level was eliminated, the functional authority of those who remained was focused solely on the collection of statistical information, the functional authority of the statistical offices in the regions and Kyiv city was limited to four processes - "collection", "processing", "analysis" and "dissemination".

In future, we intend to continue the work on improvements in the structure of the SSSU apparatus, the review of the role and responsibilities of the territorial bodies of the state statistics with the aim of enhanced efficiency as well as on reallocation of the staff between the territorial and central levels to ensure the enhancement of the analytical capacity of the SSSU. One of the first steps in this direction should be the integration of the Main Department of Regional Statistics, reduction of the staff number there and merger of the Main Department of Regional Statistics with the SSSU apparatus.

In accordance with the agreements reached with Eurostat in January 2016, the SSSU was visited by the EU expert mission with the aim to conduct the Global Assessment of the national system of official statistics of Ukraine for its compliance with the European standards. The assessment will contribute to further improvement of the SSSU activity and the harmonization of the national statistical system with international recommendations, standards and best practices. The recommendations, which will be received by the results of the Global Assessment of the national system of official statistics of Ukraine in 2016, will serve as the basis for subsequent long-term program of the state statistics development.

\section{О. Г. Осауленко,}

доктор наук з державного управління, професор, член-кореспондент НАН України,

Заслужений економіст України,

ректор,

Національна академія статистики, обліку та аудиту

\section{Досвід упровадження національних принципів діяльності в органах державної статистики України}

У статті аналізується роль фундаментальних принципів офіційної статистики в розвитку української статистичної системи та 11 адаптації до міжнародних стандартів.

Прийняття та реалізація фундаментальних принципів, їх подальший розвиток у Кодексі практики европейської статистики (2005р.) і тлумачення в Національних принципах української офіційної 
статистичної діяльності (2010р.) стали чітким орієнтиром для встановлення пріоритетів у державній статистичній діяльності. Слід зазначити, що не всі принципи можуть бути однаково легко реалізовані в чинній статистичній практиці. Навіть сьогодні, через два десятиліття після прийняття фундаментальних принципів офіційної статистики, все ще існуе низка дискусійних питань їх практичної імплементапії.

Особлива увага приділяється формулюванню національних принципів української офіційної статистичної діяльності, які засновані на Кодексі практики європейської статистики і включають систему показників PARIS 21. Ці принципи були розроблені й імплементовані з метою створення підгрунтя для подальшого зміцнення інституційного потенціалу національної статистичної служби, реалізації кращих практик європейської статистики, і на цій основі - для підвищення довіри користувачів до офіційної статистики і забезпечення високої якості статистичної інформації.

Ключові слова: Кодекс практики європейської статистики, статистичні стандарти Свростату, національні принципи украӥнської офіційної статистичної діяльності, самооцінка, процесно орієнтований nidxid.

\section{О. Г. Осауленко,}

доктор наук по государственному управлению, профессор,

член-корреспондент НАН Украины,

Заслуженный экономист Украины,

ректор,

Национальная академия статистики, учета и аудита

\section{Опыт внедрения национальных принципов деятельности в органах государственной статистики Украины}

В статье анализируется роль фундаментальных принципов официальной статистики в развитии украинской статистической системы и ее адаптации к международным стандартам.

Принятие и реализация фундаментальных принципов, их дальнейшее развитие в Кодексе практики европейской статистики (2005 г.) и толкование в Национальных принципах украинской официальной статистической деятельности (2010 г.) стали четким ориентиром для установления приоритетов в государственной статистической деятельности. Следует отметить, что не все принципы могут быть одинаково легко реализованы в действующей статистической практике. Даже сегодня, спустя два десятилетия после принятия фундаментальных принципов официальной статистики, все еще существует ряд дискуссионных вопросов их практической имплементации.

Особое внимание уделяется формулировке национальных принципов украинской официальной статистической деятельности, которые основаны на Кодексе практики европейской статистики и включают систему показателей PARIS 21. Эти принципы были разработаны и имплементированы с целью создания основы для дальнейшего укрепления институционального потенциала национальной статистической службы, реализации лучших практик европейской статистики, и на этом базисе - для повышения доверия пользователей к официальной статистике и обеспечения высокого качества статистической информации.

Ключевые слова: Кодекс практики европейской статистики, статистические стапдарты Евростата, национальные принципь украинской официальной статистической деятельности, самооценка, процессно ориентированный подход.

Bibliographic description for quoting:

Osaulenko, O. H. (2017). Experience of Introduction of National Principles Governing the Activity of the State Statistics Bodies of Ukraine. Statystyka Ukrainy - Statistics of Ukraine, 1, 56-60 [in English].

Бібліографічний опис для цитування:

Осауленко О. Г. Досвід упровадження національних принципів діяльності в органах державної статистики України (публікується англійською мовою) / О. Г. Осауленко // Статистика України. - 2017. № 1. - C. 56-60. 